University of Massachusetts Amherst

ScholarWorks@UMass Amherst

Travel and Tourism Research Association: Advancing Tourism Research Globally

\title{
Assessing Airbnb as a disruptive innovation relative to hotels: Substitution and comparative performance expectations
}

Daniel Guttentag

Follow this and additional works at: https://scholarworks.umass.edu/ttra

Guttentag, Daniel, "Assessing Airbnb as a disruptive innovation relative to hotels: Substitution and comparative performance expectations" (2017). Travel and Tourism Research Association: Advancing Tourism Research Globally. 19.

https://scholarworks.umass.edu/ttra/2017/Academic_Papers_Visual/19

This Event is brought to you for free and open access by ScholarWorks@UMass Amherst. It has been accepted for inclusion in Travel and Tourism Research Association: Advancing Tourism Research Globally by an authorized administrator of ScholarWorks@UMass Amherst. For more information, please contact scholarworks@library.umass.edu. 


\section{Assessing Airbnb as a disruptive innovation relative to hotels: Substitution and comparative performance expectations}

\section{Introduction}

Airbnb, a service permitting ordinary people to rent residences to tourists, recently has enjoyed extremely rapid growth and has shifted the tourism accommodation landscape. Airbnb's success partly comes from continuous innovations that improve the service and widen Airbnb's customer base. For example, Airbnb has introduced various identity verification mechanisms to promote security, created a "Superhost" status to help guests find top hosts, and made various efforts to attract business travellers. Nonetheless, within the hotel industry there remains significant debate regarding Airbnb, with some viewing it as a threat and others skeptical of its impacts.

Consequently, the purpose of this study was to examine Airbnb's potential to impact hotels, by investigating the extent to which Airbnb is used as a hotel substitute and by comparing Airbnb guests' performance expectations for Airbnb with that of hotels. These analyses also provide empirical insight into Airbnb's status as a "disruptive innovation."

\section{Literature review}

\section{Airbnb's impacts on hotels}

Research investigating Airbnb's hotel impacts has primarily been supply-sided. Zervas et al. (2015) found that in Texas a 10\% increase in Airbnb listings corresponded with a $0.37 \%$ decrease in hotel room revenue, and the impacts were greatest at lower-end hotels, independent hotels, and hotels without much business clientele. Lane and Woodworth (2016), working for the real estate company CBRE, found Airbnb represented a growing 1.4\% of U.S. hotel demand, and had a more significant presence in large cities. The tourism research firm HVS (2015) estimated that in the 12 months ending August 2015 Airbnb caused a direct loss of \$451 million for New York City hotels. In contrast, the hotel performance tracking firm STR concluded Airbnb was not siphoning away Manhattan hotel customers or limiting hotel pricing even on high occupancy nights (Haywood, 2016). This supply-side research provides important insights, yet is inevitably influenced by many confounding variables impacting hotel performance.

Nowak et al. (2015), working for Morgan Stanley, conducted the only demand-side (nonAirbnb) research on Airbnb substitution. That study asked Airbnb users what accommodation alternatives Airbnb had replaced, and the top response was hotel (42\%), although it is unclear what type of hotel was used. Also, $4 \%$ claimed they would not have otherwise taken the trip. Finally, Airbnb has released roughly two dozen destination-specific economic impact reports, which often state about $30 \%$ of Airbnb guests would not have otherwise visited a destination or stayed as long without Airbnb. Unfortunately, combining these two statements into a single category makes it impossible to know the especially important first percentage.

\section{Accommodation choice}

Many studies have explored tourists' hotel choices, typically by having respondents rate the importance of different hotel attributes. This research has identified numerous attributes driving hotel choice, such as cleanliness, location, reputation, price, service quality, room comfort, and security (e.g., Chu \& Choi, 2000; Dolnicar \& Otter, 2003). In contrast, far fewer studies have explored Airbnb guests' motivations for using the service. Guttentag (2015) proposed three key appeals - price, household amenities, and authenticity; Tussyadiah (2015) found peer-to-peer short-term rental users were motivated by three factors - sustainability, community, and 
economic benefits; and Nowak et al. (2015) found the top reasons Airbnb users chose the service were "cheaper price," "location," and "authentic experience."

Whereas the hotel choice literature has focused on the decision between hotel properties, the Airbnb choice literature has focused on Airbnb use more generally. These two areas of literature also have considered mostly distinct attributes, with the Airbnb literature focusing on Airbnb's unique characteristics (and therefore its strengths) instead of those typically examined in hotel studies. However, to understand their competition, it is important to understand how Airbnb compares with hotels along hotels' traditional attributes.

\section{Disruptive innovation}

As described by Christensen (1997) and Christensen and Raynor (2003), a disruptive innovation is a product that underperforms in comparison with existing products' primary performance attributes. However, disruptive innovations introduce an alternative package of benefits generally centred on being cheaper, simpler, smaller, and/or more convenient. In other words, they are inferior "good enough" products that modify the prevailing value proposition. As the disruptive product improves over time, it can increasingly satisfy the demands of mainstream consumers who adopt it as a substitute for existing products. As Guttentag (2015) suggested, this concept seemingly applies well to Airbnb, as Airbnb appears to underperform hotels when considering traditional hotel performance attributes like cleanliness, yet Airbnb offers alternative benefits (e.g., economic savings, authenticity). However, Airbnb's status as a disruptive innovation has never been empirically examined.

There is no precise definition for what characteristics define disruptive innovations. As mentioned, they have been described as cheaper, simpler, smaller, and/or more convenient (Christensen, 1997), but such statements are not precise enough for measurement. Various studies predicting or assessing disruptiveness have attempted to overcome these ambiguities by determining whether a product aligns with the classic characteristics of disruptive innovation. These studies have relied on market research or industry experts (e.g., Keller \& Hüsig, 2009).

\section{Methods}

Tourists who had used Airbnb during the previous 12 months were recruited to complete an online survey in the fall of 2015. Due to the challenges in recruiting such a sample, a multipleframe non-random online sampling approach was used. The majority of the respondents were recruited via six large travel-themed Facebook groups based around major Canadian cities. Additional respondents were recruited via Mechanical Turk (an online panel), and through a handful of other sampling approaches, such as publishing invitation messages on travel-themed Twitter feeds and putting a referral link in the survey.

The survey items were primarily Likert scale and multiple choice, and focused on respondents' most recent Airbnb stays. To measure Airbnb substitution, a question asked the most likely form of accommodation that would have been used if Airbnb and other similar peerto-peer accommodation services did not exist. Chi-square tests then compared substitution behaviours of different groups, and standardized residuals highlighted significant group differences. Also, the survey included a question on how using Airbnb affected trip duration, which assessed Airbnb's impact on destination visitor nights and provided insight into Airbnb's combination of these two categories in its reports.

To examine how Airbnb is perceived versus hotels, the survey assessed performance expectations of Airbnb, in addition to a hypothetical nearby budget hotel/motel, mid-range hotel, 
and upscale hotel, along various attributes. Ten attributes were considered, with seven supposed hotel strengths based on the hotel choice literature (e.g., Chu \& Choi, 2000; Dolnicar \& Otter, 2003) - cleanliness, comfort, confidence quality would meet expectations, ease of placing reservation, ease of checking in/out, ease of resolving unexpected problems, and security. Also, there were three items related to Airbnb's unique value proposition -experiential items related to authenticity and uniqueness, and a price item. The comparative performance expectations of Airbnb and the different hotel classes were analyzed with paired t-tests.

The applicability of the disruptive innovation concept was assessed based on both substitution and performance expectations. Because disruption inherently involves substitution, Airbnb's use as a substitute provided an indication of whether disruption was occurring. Because disruptive innovations underperform along traditional attributes but introduce a new value proposition, Airbnb's performance expectations relative to hotels indicated its consistency with the concept. This analysis represented the first attempt at assessing a disruptive innovation using consumers' behaviour and product attribute performance evaluations, rather than market research or industry experts.

\section{Results}

Following data screening, the final sample consisted of 844 respondents $-72.4 \%$ from the Canadian travel-themed Facebook groups, 16.4\% from Mechanical Turk, 10.3\% from other sampling frames, and $0.9 \%$ of unspecified origin. The sample was majority female, mostly between the ages of 21 and 40, well-educated, and fairly wealthy. Also, during their most recent Airbnb stay, most respondents had been travelling for leisure, stayed in an entire home, and stayed for two to four nights. To assess sample representativeness, numerous sample characteristics were compared with characteristics of Airbnb's guest population, as gleaned from its economic impact reports. Looking at variables like age and average length of stay, this analysis demonstrated high levels of consistency.

\section{Hotel substitution}

Nearly two-thirds of the respondents (64.8\%) indicated they used Airbnb as a hotel substitute. In particular, many indicated they would have otherwise stayed in a mid-range hotel (43.1\%), whereas upscale hotels were much less commonly indicated. Also, many indicated they used Airbnb as a hostel (16.6\%) or bed-and-breakfast (9.9\%) substitute. Only $2.3 \%$ claimed they used Airbnb to take a trip they would not have otherwise taken. Also, 26.5\% indicated their choice to use Airbnb increased their trip length, and $0.8 \%$ indicated Airbnb decreased it.

Chi-square tests found significant differences $(p<0.05)$ between various groups.

Regarding age, younger respondents were more likely to use Airbnb as a hostel substitute and older respondents were more likely to use Airbnb as a bed-and-breakfast substitute. Regarding financial status, respondents of less wealth were more likely to use Airbnb as a substitute for unpaid accommodation and hostels, and those with more wealth were more likely to use Airbnb as a substitute for bed-and-breakfasts, mid-range hotels, and upscale hotels. Regarding backpacker status, backpackers were more likely to use Airbnb as a substitute for a hostel or a budget hotel/motel. Regarding the type of Airbnb accommodation used, respondents who stayed in shared accommodation were more likely to use Airbnb as a hostel substitute, and those who stayed in an entire home were more likely to use Airbnb as a mid-range or upscale hotel substitute. Regarding travel party, respondents travelling with children were more likely to use Airbnb as a mid-range hotel substitute and less likely to use it as a hostel substitute. Statistically 
significant differences also were found between respondents who had used Airbnb different numbers of times, but there was no obvious pattern in the results. Finally, no significant differences were found when comparing respondents with different lengths of stay or different amounts of time having used Airbnb.

\section{Performance expectations}

T-tests found nearly every comparison of attribute performance expectations between Airbnb and the various classes of hotels to be significant $(p<0.05)$. Airbnb was expected to outperform budget hotels/motels for evert attribute but one ('ease of checking in/out'). Airbnb was expected to outperform mid-range hotels with regards to Airbnb's supposed strengths ('authenticity,' 'uniqueness,' and 'price') and several supposed hotel strengths ('cleanliness,' 'comfort,' and 'confidence that the overall quality would meet expectations'), but Airbnb was expected to underperform mid-range hotels with regards to 'ease of placing a reservation,' 'ease of checking in/out,' 'ease of resolving unexpected problems,' and 'security.' Finally, Airbnb was expected to underperform upscale hotels with regards to all of the supposed hotel strengths, and to outperform upscale hotels with regards to all of the supposed Airbnb strengths.

\section{Discussion}

\section{Airbnb as a hotel substitute}

This study found Airbnb is used almost wholly as a substitute for existing accommodations, generally for hotels and especially for mid-range hotels. Also, Airbnb appears to very rarely lead to tourists taking trips they would not have otherwise taken. These results are fairly consistent with supply-side research by Zervas et al. (2015), yet this study's demand-side perspective is better for estimating Airbnb's future impacts and avoids the confounding variables that complicate supply-side analyses. Moreover, this study is the first to examine substitution by different types of Airbnb guests, and it was found that Airbnb guests who were wealthier, nonbackpackers, staying in entire homes, or travelling with children were more likely to use Airbnb as a substitute for mid-range and/or upscale hotels.

For hotels, this substitution question is critically important. Airbnb claims it complements rather than competes with hotels, but this study's findings question such claims. The hotel industry's reaction to Airbnb has been mixed, and many hoteliers have remained skeptical of Airbnb's impacts. Skepticism is understandable within the upscale market given Airbnb's current limited impact on upscale hotels. Nevertheless, the process of disruptive innovation suggests upscale hoteliers should view Airbnb's impacts on budget and mid-range hotels as a possible harbinger (Christensen, 1997). For destinations, Airbnb's role as a hotel substitute means it may reduce visitors' expenditure; however, Airbnb guests may spend their accommodation savings elsewhere in a destination. Indeed, this study found that a noteworthy percentage of Airbnb guests increase their trip length because of Airbnb, which is consistent with findings by Tussyadiah and Pesonen (2015). However, the sizeable percentage of respondents who increased their trip length due to Airbnb, combined with the much smaller percentage who used Airbnb to take a trip they would not have otherwise taken, raises questions about Airbnb's combination of these two groups in its economic impact reports. The findings suggest Airbnb may be combining these groups to avoid highlighting the service's inability to encourage significant additional visitation.

\section{Performance expectations}


When considering performance expectations regarding key hotel attributes (e.g., cleanliness and security), Airbnb appears to outperform budget hotels/motels, underperform upscale hotels, and have mixed outcomes versus mid-range hotels. When considering attributes central to Airbnb's unique value proposition, Airbnb is expected to outperform all three hotel classes. These findings reflect positively on Airbnb, but also highlight some areas where Airbnb could improve. For example, concerns regarding Airbnb security are noteworthy because trust and safety fears are key barriers to Airbnb adoption (Tussyadiah, 2015). Likewise, Airbnb users did not feel it was especially easy to place reservations, which is noteworthy because Tussyadiah (2015) found "lack of efficacy" to be a key barrier to Airbnb use. Airbnb recently introduced "Instant booking" to facilitate the reservation process at some listings, but Airbnb still could benefit from advertising about the service's simplicity.

\section{Airbnb: A disruptive innovation?}

The findings suggest Airbnb is not truly a disruptive innovation relative to budget hotels/motels, despite being a common substitute, because Airbnb users perceive it as a superior product. In contrast, the performance expectations relative to upscale hotels represent the classic pattern of disruptive innovation, but because Airbnb is infrequently used as an upscale hotel substitute the service is best seen as a disruptive threat instead of a current disruptor. Finally, Airbnb was most commonly used as a mid-range hotel substitute, but Airbnb's varied performance expectations versus mid-range hotels (including outperforming mid-range hotels along several key dimensions like cleanliness) suggest some parallels with the disruptive innovation framework, without full consistency.

This study highlights several key questions and issues about disruptive innovations. The findings demonstrate how innovations are only disruptive relative to another product (Christensen, 2006). The findings also underscore the common misapplication of the term to over-performing products (Christensen, 2006). Moreover, the findings show the benefit of measuring consumer perceptions, as product users' perceptions give the ultimate assessment of perceived underperformance. Finally, the findings illustrate the difficulty in establishing a binary disruptiveness test, thereby highlighting the value of instead noting gradations of consistency with the concept.

\section{Conclusion}

This study offers important insight into Airbnb's impacts on the hotel sector by showing that many Airbnb guests use the service in place of a hotel, and demonstrating that Airbnb guests hold high expectations of the service. This study also shows that the disruptive innovation concept is only somewhat applicable to Airbnb. There were various limitations to this research, including the use of an online non-probability sample that primarily resided in North America. Additionally, respondents' performance expectations for Airbnb may have been influenced by their actual Airbnb experiences. This research also highlights directions for future research. For example, it would be useful to better understand the Airbnb choice process and to compare Airbnb guests' Airbnb performance expectations with that of hotel guests. Moreover, this study introduced a new consumer-based approach for assessing disruptive innovations, and this approach can be used to investigate other apparent disruptive innovations in tourism and beyond. 


\section{References}

Christensen, C. M. (1997). The innovator's dilemma: When new technologies cause great firms to fail. Boston, MA: Harvard Business School Press.

Christensen, C. M. (2006). The ongoing process of building a theory of disruption. Journal of Product Innovation Management, 23(1), 39-55.

Christensen, C. M., \& Raynor, M. E. (2003). The innovator's solution: Creating and sustaining successful growth. Boston, MA: Harvard Business School Press.

Chu, R. K., \& Choi, T. (2000). An importance-performance analysis of hotel selection factors in the Hong Kong hotel industry: A comparison of business and leisure travellers. Tourism Management, 21(4), 363-377.

Dolnicar, S., \& Otter, T. (2003). Which hotel attributes matter? A review of previous and a framework for future research. In T. Griffin \& R. Harris (Eds.), Proceedings of the 9th Annual Conference of the Asia Pacific Tourism Association (APTA) (pp. 176-188.), University of Technology Sydney, Australia.

Guttentag, D. (2015). Airbnb: Disruptive innovation and the rise of an informal tourism accommodation sector. Current Issues in Tourism, 18(12), 1192-1217.

Haywood, J. (2016, February 11). STR: Airbnb's impact on Manhattan compression. Hotel News Now. Retrieved from http://www.hotelnewsnow.com/Articles/30351/STR-Airbnbsimpact-on-Manhattan-compression.

HVS. (2015). Airbnb and impacts on the New York City lodging market and economy. HVS. Retrieved from http://www.hanyc.org/wp-content/uploads/2015/10/HVS-Impact-StudyFINAL-Airbnb-and-the-NYC-Lodging-Market-10-27-15-copy.pdf.

Keller, A., \& Hüsig, S. (2009). Ex ante identification of disruptive innovations in the software industry applied to web applications: The case of Microsoft's vs. Google's office applications. Technological Forecasting and Social Change, 76(8), 1044-1054.

Lane, J., \& Woodworth, R. M. (2016). The sharing economy checks in: An analysis of Airbnb in the United States. CBRE. Retrieved from

http://cbrepkfcprod.blob.core.windows.net/downloads/store/12Samples/An_Analysis_of_ Airbnb_in_the_United_States.pdf.

Nowak, B., Allen, T., Rollo, J., Lewis, V., He, L., Chen, A., Wilson, W. N., Costantini, M., Hyde, O., Liu, K., Savino, M., Chaudhry, B. A., Grube, A. M., Young, E. (2015). Global insight: Who will Airbnb hurt more - hotels or OTAs?. Morgan Stanley Research. Retrieved from http://linkback.morganstanley.com/web/sendlink/webapp/f/9lf3j1683pcc-g01h-b8bf005056013100? store $=0 \& d=U w B S Z X N 1 Y X J j a F 9 N U w B i N j V j Y z A y N i 04 N G Q 2 L T E x Z T$ UtYjFIMi03YzhmYTAzZWU4ZjQ\%3D\&user=bdvpwh9kcvqs-

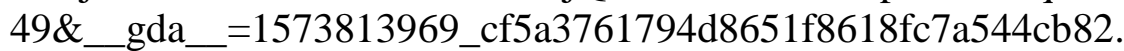

Tussyadiah, I. (2015). An exploratory study on drivers and deterrents of collaborative consumption in travel. In Tussyadiah, I. \& Inversini, A. (Eds.), Information \& Communication Technologies in Tourism 2015 (pp. 817-830). Switzerland: Springer International Publishing.

Tussyadiah, I., \& Pesonen, J. (2015). Impacts of peer-to-peer accommodation use on travel patterns. Journal of Travel Research. Published online October 12, 2015.

Zervas, G., Proserpio, D., \& Byers, J. (2015). The rise of the sharing economy: Estimating the impact of Airbnb on the hotel industry. Boston University School of Management Research Paper Series, No. 2013-16. 